\title{
Strategi Bimbingan dan Pelatihan Guru Dalam Pembelajaran Menggunakan Aplikasi Google Pada Pembelajaran Daring Untuk Meningkatkan Efektifitas Belajar Siswa Dimasa Pandemi Covid-19
}

\author{
Nyi Mulyanah ${ }^{1}$, Ana Andriani² \\ 1,2Program Studi Magister Pendidikan Dasar, \\ Universitas Muhammadiyah Purwokerto \\ e-mail: nyimulyanah2@gmail.com
}

\begin{abstract}
This study aims to improve the ability and professionalism of teachers in using the google application in online learning to increase the effectiveness of student learning during the Covid-19 pandemic at Korwilcam Dindik Somagede, Banyumas Regency. This research method uses the Mixed Methods method while the research model is Sequential Expplonatory. The empirical reality shows that the current condition is very concerned about the decline in the quality of learning in schools today with the Distance Learning (PJJ) pattern. Some of the causes are the lack of availability of tools I media owned by the school, the lack of the ability of teachers to operate tools / media such as laptops; less supportive internet access for the smooth running of online learning; not all students have smartphones. Based on the analysis of needs, $86.7 \%$ of the 214 teachers agreed to carry out guidance and training on the use of google (google form, google classroom, google drive, and google meet). The use of the google application in PJJ teachers acts as a motivator, facilitator, mediator, and communicator. The ability of teachers in online learning using the Google application has increased, the number of participants who took part in the guidance program was 120 people, all participants received a certificate of graduation. Seeing the results of these graduates can be declared successful for the training program using the Google application.
\end{abstract}

Keywords: Guidance and Training, Online Learning, Effective Learning, Covid-19 Pandemic

Abstrak. Penelitian ini bertujuan untuk meningkatkan kemampuan dan profesionalitas guru dalam penggunaan aplikasi google pada pembelajaran daring untuk meningkatkan efektivitas belajar siswa selama masa pandemi covid-19 di Korwilcam Dindik Somagede Kabupaten Banyumas. Metode penelitian ini menggunakan metode Mixed Methods sedangkan model penelitiannya Sequential Expplonatory. Realitas empirik memperlihatkan bahwa kondisi saat ini sangat meprihatinkan menurunnya kualitas pembelajaran di sekolah saat ini dengan pola Pembelajaran Jarak Jauh (PJJ). Beberapa penyebabnya adalah kurangnya ketersediaan alat/media yang dimiliki sekolah, kurangnya kemampuan guru dalam mengoperasikan alat/media seperti laptop; akses internet yang kurang mendukung untuk kelancaran pembelajaran daring; tidak semua siswa memiliki smartphone. Berdasarkan analisis kebutuhan 86,7\% dari 214 guru setuju untuk dilaksanakan bimbingan dan pelatihan penggunaan google (google form, google classroom, google drive, dan google meet). Penggunaan aplikasi google dalam PJJ guru berperan sebagai motivator, fasilitator, mediator, dan komunikator. Kemampuan guru dalam pembelajaran daring dengan menggunakan aplikasi google meningkat, jumlah peserta yang mengikuti bimlat sebanyak 120 orang, semua peserta mendapatkan sertifikat kelulusan. Melihat hasil lulusan tersebut dapat dinyatakan berhasil untuk program diklat penggunaan aplikasi google.

Nyi Mulyanah, Ana Andriani. Strategi Bimbingan dan Pelatihan Guru Dalam Pembelajaran Menggunakan Aplikasi Google Pada Pembelajaran Daring Untuk Meningkatkan Efektifitas Belajar Siswa Dimasa Pandemi Covid-19|67 
Kata kunci: Bimbingan dan Pelatihan, Pembelajaran Daring, Pembelajaran Efektif, Pandemi Covid19

\section{PENDAHULUAN}

Awal Maret 2020 ditetapkan oleh pemerintah tentang aturan Work From Home (WFH) dan Study From Home (SFH) hal ini menyebabkan terjadinya perubahan besar terhadap pola hidup masyarakat termasuk juga di dalamnya pada dunia pendidikan. Siswa yang sebelumnya terbiasa belajar dan berkelompok di sekolah tiba-tiba harus belajar secara mandiri di rumah. Kondisi ini bertujuan untuk memutus rantai penyebaran Pandemi Covid-19. Tentu saja hal ini akan menimbulkan dampak terhadap psikis siswa.

Surat Edaran (SE) yang dikeluarkan pemerintah pada 18 Maret 2020 berisi tentang segala kegiatan di dalam dan di luar ruangan di semua sektor sementara waktu ditunda demi mengurangi penyebaran corona terutama pada bidang pendidikan. Pada tanggal 24 maret 2020 Menteri Pendidikan dan Kebudayaan Republik Indonesia mengeluarkan Surat Edaran Nomor 4 Tahun 2020 Tentang Pelaksanaan Kebijakan Pendidikan Dalam Masa Darurat Penyebaran Covid-19, dalam Surat Edaran tersebut dijelaskan bahwa proses belajar dilaksanakan di rumah melalui pembelajaran daring/jarak jauh dilaksanakan untuk memberikan pengalaman belajar yang bermakna bagi siswa. Belajar di rumah dapat difokuskan pada pendidikan kecakapan hidup antara lain mengenai pandemi Covid-19. Dampak virus COVID-19 terjadi diberbagai bidang seperti sosial, ekonomi, pariwisata dan pendidikan.

Pembelajaran melalui aplikasi merupakan inovasi pendidikan untuk menjawab tantangan akan ketersediaan sumber belajar yang variatif. Keberhasilan dari suatu model ataupun media pembelajaran tergantung dari karakteristik peserta didiknya. Tidak semua siswa akan sukses dalam mengikuti pembelajaran online karena dipengaruhi oleh beberapa faktor yaitu karakteristik atau kompetensi individu itu sendiri, keadaan atau kondisi sosialnya juga faktor lingkungan mudah dan sulitnya mengakses internet.

Pembelajaran daring dilakukan menyesuaikan kemampuan masingmasing sekolah. Belajar daring (online) dapat menggunakan teknologi digital seperti google classroom, goole form, rumah belajar, zoom, video converence, telepon atau live chat dan lainnya. Namun yang pasti harus dilakukan adalah pemberian tugas melalui pemantauan pendampingan oleh guru melalui google form sehingga anak betul-betul belajar. Kemudian guru-guru juga bekerja dari rumah (Work From Home) berkoordinasi dengan orang tua, bisa melalui video call maupun foto kegiatan belajar anak dirumah untuk memastikan adanya interaksi antara guru dengan orang tua.

Ada beberapa persoalan yang guruguru hadapi di Korwilcam Dindik Somagede selama menjalankan sistem WFH ini antara lain; 1) kondisi psikis siswa yang tiba-tiba libur panjang karena takut dampak dari covid-19 sedangkan tidak ada persiapan apapun dalam hal ini, 2) sumber belajar yang tadinya siswa dapat pinjam buku teks secara bergantian otomatis tidak dapat dilakukan; 3) menurunnya daya kemampuan berpikir 
siswa diakibatkan penyesuaian dari kegiatan sekolah menjadi di rumah; 4) satu-satunya sumber belajar di rumah adalah internet; 5) tidak semua siswa di kelas memiliki smartphone dan tidak semua memiliki aplikasi yang mendukung serta kuota internet; 6) siswa belum ada kesadaran dalam mengumpulkan tugas yang diberikan oleh guru; 8) terjadi komunikasi satu arah ketika siswa tidak bertanya atau mengerjakan tugas,

Tujuan dari model pembelajaran daring saat ini adalah siswa bisa belajar dari rumah untuk memutus mata rantai wabah pandemi COVID-19, mempersiapkan peserta didik yang siap bersaing di era digital, proses pembelajaran jadi lebih rileks, rajin menyusun tentang waktu untuk mengerjakan tugas/belajar materi yang diberikan, mengirim tugas tepat waktu, lebih banyak waktu untuk belajar. Mewujudkan suasana yang efektif dan kondusif dalam pembelajaran selama masa pandemi Covid-19 ini, Korwilcam Dindik Somagede mengadakan Bimbingan dan Pelatihan Guru Profesional Penggunaan Aplikasi google untuk pembelajaran daring yang dilaksanakan selama 3 (tiga) hari dengan durasi pelaksanaan $30 \%$ teori dan $70 \%$ praktik. Kegiatan ini diawali dengan wawancara untuk mengetahui sejauhmana pemahamanan guru sebagai peserta bimlat terhadap penggunaan aplikasi google khususnya yang bisa digunakan untuk Pembelajaran Jarak Jauh (PJJ). Adapun hasil secara keseluruhan hanya $18,3 \%$ jumlah peserta yang memahami penggunaan aplikasi google dalam pembelajaran. Maka perlu startegi bimbingan dan pelatihan penggunaan aplikasi google dalam pembelajaran untuk meningkatkan efektifitas belajar siswa.

\section{METODE}

Metode penelitian ini menggunakan metode penelitian kombinasi (Mixed Methods). Menurut Sugiyono (2011:404) bahwa, Metode penelitian kombinasi (mixed methods) adalah "Suatu metode penelitian yang mengkombinasikan atau menggabungkan antara metode kuantitatif dan metode kualitatif untuk digunakan secara bersama-sama dalam suatu kegiatan penelitian sehingga diperoleh data yang lebih komprehensif, valid, reliabel dan objektif." Selain itu Creswell (2010:5) mengemukakan penelitian metode campuran merupakan pendekatan penelitian yang mengkombinasikan atau mengasosiasikan bentuk kualitatif dan bentuk kuantitatif. Sebelumnya guru mengobservasi kesulitan-kesulitan dan masalah-masalah yang dihadapi siswa dalam PBM, guru melaksanakan pengkajian atau telaah yang dilakukan oleh kelompok untuk menggambarkan strategi-strategi pembelajaran yang dilakukan dan mendapatkan data tentang cara belajar siswa, berbagi pengalaman dan pengetahuan tentang temuan dan hasil observasi, dan menggambarkan kesimpulan tentang kemajuan siswa dalam mencapai tujuan belajar, (Andriani, A., \& Wakhudin, W:2020). Bahri, Djamarah, Syaiful (2010: 375), pembelajaran efektif merupakan pembelajaran yang memungkinkan anak didik dapat belajar dengan mudah dan menyenangkan. Proses belajarnya mudah, terhindar dari ancaman, hambatan gangguan. Menurut Nasution, S ( 2002: 10-12), mengemukakan bahwa pembelajaran yang efektif merupakan proses sirkuler yang terdiri atas 4 komponen, yaitu mengadakan penilaian, perencanaan pengajaran, mengajar dengan efektif, latihan dan reinforcement. 
Pendekatan ini melibatkan asumsiasumsi filosofis, aplikasi pendekatanpendekatan kualitati dan kuantitatif, percampuran (mixing) kedua pendekatan tersebut ke dalam satu penelitian. Pendapat Sugiyono dan Creswell tentang mixed methode di atas bahwa, metode penelitian kombinasi adalah metode penelitian yang menggunakan dua metode yaitu metode penelitian kuantitatif dan kualitatif untuk digunakan dalam suatu kegiatan penelitian. Sehingga diperoleh data yang lebih lengkap dan menyeluruh. Desain penelitian ini menggunakan Sequential Explanatory yaitu Model penelitian Sequential Explonatory design dicirikan dengan melakukan pengumpulan data dan analisis data kuantitatif pada tahap pertama, dan diikuti dengan pengumpulan dan analisis data kualitatif pada tahap kedua, guna memperkuat hasil penelitian kuantitatif yang dilakukan pada tahap pertama. (Sugiyono, 2011: 409).

Kegiatan bimbingan dan pelatihan diawali dengan penelitian pendahuluan melalui wawancara dengan data kualitatif, menghasilkan data kebutuhan peserta dalam pembelajaran di masa pandemi Covid-19. Berdasarkan data kebutuhan tersebut, maka dibentuklah panitia bimbingan dan pelatihan penggunaan aplikasi google dalam pembelajaran daring oleh Koordinator Korwilcam Dindik Somagede. Pretest dilaksanakan untuk mengetahui kedalaman pemahaman peserta terhadap aplikasi google. Panitia penyelenggara bimbingan dan pelatihan selama pelaksanaannya berpedoman pada silabus yang telah disusun narasumber yang dilatarbelakangi oleh kebutuhan peserta melalui penelitian pendahuluan. Isi materi dalam silabus terdiri dari google form, google classroom, google drive, dan google meet.

Selama pelaksanaan bimbingan dan pelatihan narasumber menggunakan metode yang bervariasi selain ceramah, tanya jawab, penugasan dan presentasi. Postest dilaksanakan untuk mengukur tingkat pemahaman peserta terhadap materi yang telah diberikan oleh narasumber selama pelaksanaan bimbingan dan pelatihan. Kegiatan bimbingan dan pelatihan diadakan evaluasi sebagai bahan koreksi untuk peningkatan kualitas penyelenggraan bimbingan dan pelatihan berikutnya. Evaluasi dilaksankan terhadap tahapan bimbingan dan pelatihan, pelaksanaan bimbingan dan pelatihan, dampak bimbingan dan pelatihan. Tanggapam peserta terhadap pelaksanaan bimbingan dan pelatihan selanjutnya interpretasi data dan kesimpulan.

Teknik keabsahan data yang digunakan dalam penelitian ini adalah triangulasi, untuk mengecek kebenaran data dan dapat menyelidiki tafsiran peneliti terhadap data. Triangulasi dalam pengujian kredibilitas sebagai pengecekan data dari berbagai sumber dengan berbagai cara. Penelitian ini dilakukan menggunakan data wawancara dengan informan, observasi terhadap kegiatan daring yang dilaksanakan guru dalam mengefektifkan belajar siswa, dan dokumentasi adminsitrasi dan foto-foto kegiatan yang digunakan selama pembelajaran daring.

\section{HASIL}

Tahap penelitian pedahuluan berupa analisis kebutuhan menghasilkan untuk pembelajaran daring di Korwilcam Dindik Somagede Kabupaten Banyumas menunjukkan bahwa pembelajaran daring selama pandemi Covid-19 hanya 
dilaksanakan dengan memberi tugas mengerjakan lembar tugas melalui whatsAap Group tanpa dijelaskan terlebih dahulu materi yang ada dalam lembar tugas tersebut, seharusnya didukung dengan aplikasi google yang dapat menunjang terlaksananya pembelajaran daring, baik menggunakan komputer, laptop, atau smartphone sesuai dengan kemampaun atau keahliannya. Guru belum sepenuhnya mampu untuk merancang pembelajaran daring dengan menggunakan media elektronik, belum punya ide atau gagasan untuk menggunakan pola pembelajaran online yang menyenangkan, belum memiliki kemampuan untuk membuat pembelajaran daring dengan menggunakan aplikasi google karena belum mahir dalam mengoperasikan lapotop, perlu banyak pembimbingan dalam penggunaan aplikasi google untuk pembelajaran. $86 \%$ guru diwilayah Korwilcam Dindik Somagede Kabupaten Banyumas sertuju untuk diadakan pelatihan penggunaan aplikasi google.

Simamora,

$\mathrm{H}$

(1995:287)

mengemukakan bahwa pelatihan merupakan serangkaian aktivitas yang dirancang untuk meningkatkan keahlian, pengetahuan, pengalaman, ataupun perubahan sikap seorang individu atau kelompok dalam menjalankan tugas. Strategi peneltian yang tepat adalah model bimbingan dan pelatihan menurut Sudjana (2005:78) mengembangkan model bimbingan dan pelatihan dengan sepuluh langkah.

Tahapan strategi pelaksanaan bimbingan dan pelatihan penggunaan aplikasi google meliputi identifikasi masalah menunjukkan bahwa guru belum mampu mengoperasikan laptop atau media elektronik lainnya yang bisa menunjang pembelajaran daring.
Perumusan tujuan pelatihan, penyusunan program pelatihan adalah untuk untuk memenuhi kebutuhan guru dan sebagai wahana pengembangan diri bagi guru sebagai bentuk profesionalisme guru serta tantangan untuk bisa membuat karya yang inovatif dengan pembuatan scenario pembelajaran yang produktif. Pelaksanaan bimbingan dan pelatihan penggunaan aplikasi google diselenggarakan oleh Panitia Pengembangan Profesi Guru (PPPG). Durasi praktik lebih banyak daripada teori yaitu $30 \%$ teori dan $70 \%$ praktik. Kegiatan bimbingan dan pelatihan merujuk pada Sastrodipoera (2006:122) merupakan salah satu proses pembelajaran untuk memperoleh dan meningkatkan keterampilan di luar sistem pengembangan sumber daya manusia yang berlaku dalam waktu yang relative singkat dengan metode yang lebih mengutaman praktek dari pada teori.

Data penelitian diperoleh bahwa sebanyak 26,7\% dari jumlah guru yang menjadi informan menyatakan bahwa dalam melaksanakan pembelajaran daring menggunakan smartphone. Dampak pelaksanaan bimbingan dan pelatihan penggunaan aplikasi google adalah peserta dapat mengimplementasikannya dalam melaksanakan tugas pokoknya sebagai guru melalui pembelajaran daring lebih efektif selama masa pandemi covid-19. Kepemilikan setifikat sebagai tanda kelulusan bahwa telah ikut melaksanakan bimbingan dan pelatihan selain sebagai bukti bahwa telah mengikuti kegiatan bimbingan dan pelatihan. Tanggapan peserta setelah mengikuti bimbingan dan pelatihan pada umumnya positif, baik ketuntasan belajarnya, proses pelaksanaan bimbingan dan pelatihannya termasuk materi, metode dan strategi pelaksanaannya 
dapat membantu peserta untuk memahami materi bimlat.

Hasil rata-rata peningkatan skor pengetahuan dan pemahaman materi melalui pretest-postest nilai $0-20$ menurun dari 36 orang peserta menjadi 2 orang peserta atau dari $30 \%$ menjadi 1,7 $\%$ rata-rata peningkatan skor pengetahuan dan pemahaman materi melalui pretes-postes nilai $20-40$ menurun dari 31 orang peserta menjadi 2 orang peserta atau dari $25,8 \%$ menjadi $1,7 \%$, rata-rata peningkatan skor pengetahuan dan pemahaman materi melalui pretes-postes nilai $40-60$ menurun dari 14 orang peserta menjadi 3 orang peserta atau dari $11,7 \%$ menjadi $2,5 \%$, rata-rata peningkatan skor pengetahuan dan pemahaman materi melalui pretes-postes nilai $60-80$ meningkat dari 17 orang peserta menjadi 54 orang peserta atau dari $14,2 \%$ menjadi $45 \%$, rata-rata peningkatan skor pengetahuan dan pemahaman materi melalui pretes-postes nilai $80-100$ meningkat dari 22 orang peserta menjadi 59 orang peserta atau dari $18,3 \%$ menjadi $49,1 \%$, data tersebut diuraikan dalam tabel berikut ini:

Tabel 1. Nilai Pretes dan Postes dalam Bimlat Penggunaan Aplikasi Google

\begin{tabular}{ccccccll}
\hline \multirow{2}{*}{ No } & \multirow{2}{*}{ Nilai } & \multicolumn{2}{c}{ Jumlah } & \multicolumn{2}{c}{ Prosentase } & Kenaikan/ \\
\cline { 3 - 6 } & & Pretes & Postes & Pretes & Postes & Penurunan \\
\hline 1. & $0-20$ & 36 & 2 & $30 \%$ & $1,7 \%$ & $28,3 \%$ \\
\hline 2. & $20-40$ & 31 & 2 & $25,8 \%$ & $1,7 \%$ & $24.1 \%$ \\
\hline 3. & $40-60$ & 14 & 3 & $11,7 \%$ & $2,5 \%$ & $9,2 \%$ & \\
\hline 4. & $60-80$ & 17 & 54 & $14,17 \%$ & $45 \%$ & $30,83 \%$ \\
\hline 5. & $80-100$ & 22 & 59 & $18,33 \%$ & $49,1 \%$ & $30,77 \%$ & \\
\hline
\end{tabular}

Hasil wawancara terhadap responden tentang evaluasi strategi bimbingan dan pelatihan penggunaan aplikasi google sebagain besar memberikan respon positif. Aspek perencanaan yang merespon amat baik sebanyak $77,8 \%$, baik sebanyak 15,6\% sedangkan cukup sebanyak 6,6\%. Aspek penghentian, kelanjutan dan perluasan yang menjawab amat baik sebanyak $71,1 \%$, baik sebanyak $17,8 \%$ dan yang menjawab cukup sebanyak 11,1\%. Aspek modifikasi program yang merespon amat baik sebanyak $88,8 \%$, baik sebanyak $6,7 \%$, dan cukup sebanyak 4,5\%. Aspek pendukung dan penghambat yang merespon amat baik sebanyak 55,6\%, baik sebanyak $33,3 \%$, dan cukup sebanyak 11,1\%. Sedangkan aspek motivasi dan pembinaan pengelolaan dan pelaksanaan program bimbingan dan pelatihan yang menjawab amat baik sebanyak $66,7 \%$, baik sebanyak $22,2 \%$, dan cukup $11,1 \%$. Lebih rinci dapat dilihat pada tabel berikut:

\section{Tabel 2. Hasil Evaluasi Strategi Program} Bimbingan Dan Pelatihan Penggunaan Aplikasi Google

\begin{tabular}{lllllllc}
\hline No & \multicolumn{1}{c}{ Aspek } & \multicolumn{3}{c}{ Jumlah } & \multicolumn{3}{c}{ Prosentase } \\
\cline { 3 - 8 } & A & B & C & A & B & C \\
\hline 1 & Perencanaan & 35 & 7 & 3 & 77,8 & 15,6 & 6,6 \\
\hline 2 & 32 & 8 & 5 & 71,1 & 17,8 & 11,1 \\
& $\begin{array}{l}\text { Penghentian, } \\
\text { kelanjutan, atau } \\
\text { perluasan }\end{array}$ & & & & & & \\
\hline 3 & $\begin{array}{l}\text { Modifikasi } \\
\text { program }\end{array}$ & 40 & 3 & 2 & 88,8 & 6,7 & 4,5 \\
\hline 4 & $\begin{array}{l}\text { Pendukung dan } \\
\text { penghambat }\end{array}$ & 25 & 15 & 5 & 55,6 & 33,3 & 11,1 \\
\hline 5 & $\begin{array}{l}\text { Motivasi dan } \\
\text { pembinaan } \\
\text { pengelolaan } \\
\text { dan }\end{array}$ & 30 & 10 & 5 & 66,7 & 22,2 & 11,1 \\
& & & & & & & \\
\end{tabular}
pelaksanaan program bimlat

Hasil evaluasi strategi bimbingan dan pelatihan penggunaan aplikasi google telah menunjukkan keberhasilan dilihat dari beberapa aspek, respon responden sebagian besar amat baik. Untuk memaksimalkan pelaksanaan bimbingan dan pelatihan yang akan datang perlu adanya perbaikan dalam penyusunan soal pretest dan postest lebih teliti lagi agar tidak terjadi salah persepsi bagi peserta. Kondisi perangkat pembelajaran harus

Nyi Mulyanah, Ana Andriani. Strategi Bimbingan dan Pelatihan Guru Dalam Pembelajaran Menggunakan Aplikasi Google Pada Pembelajaran Daring Untuk Meningkatkan Efektifitas Belajar Siswa Dimasa Pandemi Covid-19|72 
benar-benar disiapkan agar tidak mengalami hambatan terutama saat menggunakan wifi, pesrta harus mempersiapkan paket data sebelumnya. Pemantauan dari penyelenggara sangat dibutuhkan untuk mengetahui kondisi riil saat pelaksanaan bimbingan dan pelatihan baik dari segi peserta, sarana prasarana dan narasumber.

\section{SIMPULAN}

Berdasarkan uraian hasil penelitian yang dilakukan terhadap guru di wilayah Korwilcam Dindik Somagede pada tangagal 30 Juni sampai dengan tanggal 2 Juli 2020, maka dapat ditarik kesimpulan bahwa pelaksanaan bimbingan dan pelatihan penggunaan aplikasi google dalam pembelajaran daring untuk meningkatkan efektifitas belajar siswa dimasa pandemic covid-19 mendapat respon yang positif ditunjukan dengan mengimplementasikan hasil pelatihan di masing-masing sekolah dengan pembelajaran daring. Dampaknya adalah guru sebagai peserta memiliki kemampuan dan keterampilan dalam pembelajaran daring sehingga terjadi interaksi antara guru dan siswa walaupun hanya melalui dunia maya. Kepemilikan sertifikat sebagai bukti kelulusan dan bukti telah mengikuti kegiatan yang bisa digunakan untuk pengajuan angka kredit. Tanggapan pesertapun positif baik terhadap aspek ketuntasan belajarnya, proses pelaksanaan bimbingannya, pelatihanya, materi, metode, vahkan strategi pelaksanaannya dapat membantu peserta meningkatkan pemahaman terhadap pengetahuan dan keterampilan dalam pengunaan aplikasi google untuk pembelajaran daring. Memaksimalkan pelaksanaan bimbingan dan pelatihan yang akan datang perangkat pelatihan yaitu wifi harus dipersiapkan selain oleh peserta juga panitia supaya kendala ini tidak terulang lagi dalam kegiatan yang sama, sehungga peserta bisa lancar selama pelathan Ketika menggunakan IT.

\section{DAFTAR PUSTAKA}

Andriani, A., \& Wakhudin, W. (2020). Implementasi Pendidikan Karakter Melalui Model Pembelajaran Discovery Learning Di MIM Pasir Lor Karanglewas Banyumas. Jurnal Pengabdian Masyarakat, 1(2), 51-63. Diakses pada hari Rabu, 28 Oktober 2020, pukul.13.50 WIB.

Bahri, D. S. 2010. Guru dan anak didik dalam interaksi edukatif. Jakarta. Rineka Cipta

Nasution. S. (2002). Berbagasi Pendekatan dalam Proses Belajar dan Mengajar. Jakarta: Bumi Aksara.

Sastradipoera, K. (2006). "Pengembangan dan Pelatihan, Suatu Pendekatan Manajemen Sumber Daya Manusia". Bandung: Kappa-Sigma

Simamora, H. (1995). "Manajemen Sumber Daya Manusia", Yogyakarta : BPFE.

Sugiyono. (2011). Metode Penelitian Kuantitatif, Kualitatif dan RED. Bandung: Afabeta

Sudjana HD (2005). Strategi Pembelajaran. Bandung: Falah Production

Nyi Mulyanah, Ana Andriani. Strategi Bimbingan dan Pelatihan Guru Dalam Pembelajaran Menggunakan Aplikasi Google Pada Pembelajaran Daring Untuk Meningkatkan Efektifitas Belajar Siswa Dimasa Pandemi Covid-19|73 